\title{
ANALISIS PERBANDINGAN PERHITUNGAN HARGA POKOK PRODUKSI METODE TRADISIONAL PERUSAHAAN DENGAN METODE FULL COSTING
}

\section{(Studi Kasus UD Sari Murni Kelurahan Brang Biji Kecamatan Sumbawa)}

\author{
Ely Isa Sulastra \\ Progrma Studi Akuntansi, Fakultas Ekonomi dan Bisnis \\ Universitas Teknologi Sumbawa \\ E-mail:elyisasulastra10@gmail.com
}

\begin{abstract}
The study aims to analyze the comparison of the calculation the cost of production set by the company with the full costing method. This research was carried out on the essence of the sub-district of the subdistrict seed brackets Sumbawa data obtained through interview and documentation with the owner. In this research, the essence has been done calculation done is not right because it stiil uses calculation using a very simple method. Calculation made by the company have not calculated in detail the costs of cost incurred during the production process. This type of research is qualitative with a description approach. The calculation result show that from the calculation of the cost of production with the cost of production used by the company method that is equal to Rp.531.957.514 while using the full costing method Rp.592.161.889.
\end{abstract}

Keywords : Cost Of Good Sold,Full Costing Method

\begin{abstract}
Abstrak
Penelitian ini bertujuan untuk menganalisis perbandingan perhitungan harga pokok produksi yang ditetapkan oleh perusahaan dengan metode full costing. Penelitian ini dilaksanakan pada UD Sari Murni Kelurahan Brang Biji Kecamatan Sumbawa. Data yang diperoleh melalui wawancara, observasi dan dokumentasi dengan pemilik perusahaan. Dalam penelitian ini, UD Sari murni telah melakukan perhitungan biaya produksi, tetapi perhitungan yang dilakukan belum tepat karena masih menggunakan perhitungan dengan metode yang sangat sederhana. Perhitungan yang dilakukan oleh perusahaan belum menghitung secara terperinci biaya-biaya yang dikeluarkan selama proses produksi. jenis penelitian ini yaitu kualitatif dengan pendekatan deskriptif. Hasil perhitungan menunjukkan bahwa dari perhitungan harga pokok produksi dengan metode full costing memberikan hasil yang berbeda, apabila dibandingkan dengan harga pokok produksi yang digunakan dengan metode perusahaan yaitu sebesar Rp.531.957.514 sedangkan menggunakan metode full costing sebesar Rp.592.161.889.
\end{abstract}




\section{Kata Kunci : Harga Pokok produksi, Metode full costing}

\section{PENDAHULUAN}

Perkembangan perekonomian di Indonesia saat ini secara tidak langsung mendorong persaingan bisnis diberbagai bidang. Semua industri seperti perusahaan berlomba-lomba dalam meningkatkan mutu produksinya baik yang bersifat barang maupun jasa. Akan tetapi salah satu bidang yang tidak mengalami peningkatan yaitu bidang perindustrian. Industri yang dalam kegiatan ekonomi yang mengolah bahan mentah, bahan baku, bahan setengah jadi hingga menjadi barang jadi. Menurut Undang-undang No. 20 tahun 2008 tentang UMKM sebagai berikut :

"Usaha mikro,kecil dan menengah (UMKM) merupakan kegiatan usaha berskala kecil yang dapat dikelola oleh sekumpulan keluarga maupun kelompok perorangan yang bertujuan untuk mendirikan suatu usaha. UMKM bukan merupakan anak dari suatu perusahaan bagian maupun cabang, dari suatu perusahaan baik yang menjadi bagian langsung maupun tidak langsung dari perusahaan sesuai criteria yang telah ditentukan

Dengan bertambahnya pelaku industri UMKM persaingan akan semakin kompetitif. Pelaku usaha yang harus mampu jual produk dengan tetap memperhatikan biaya produksi yang dikeluarkan sebagai dasar menentukan harga pokok produksi, perusahaan harus menentukan metode yang tepat sehingga nantinya dapat menghasilkan laba yang sesuai dengan harapan perusahaan serta dapat bersaing dengan perusahaanlainnya. Harga pokok produksi sendiri terdiri dari beberapa unsur : biaya bahan baku, biaya tenaga kerja langsung dan biaya overhead pabrik. Harga pokok produksi menurut metode full costing terdiri dari biaya bahan baku, biaya tenaga kerja langsung, biaya overhead pabrik tetap dan biaya overhead pabrik variabel. Dalam metode full costing, biaya overhead pabrik baik yang bersifat tetap maupun variabel dibebakan/dimasukan dalam perhitungan harga pokok produksi berdasarkan tarif biaya overhead pabrik yang sesungguhnya. Komara dan Sudarma, 2016)

UD Sari Murni merupakan perusahaan manufaktur dalam bidang industri tahu tempe yang terdapat di jalan Cendrawasih Rukun Tetangga (RT) 001 Rukun Warga (RW) 003 Kelurahan Barang Biji Kecamatan Sumbawa yang telah berdiri dari tahun 1996 sekitar 22 tahun telah beroperasi. Perusahaan ini menggunakan bahan baku dalam proses produksinya menggunakan kedelai yang diolah menjadi tahu dan tempe. Alat yang digunakan dalam proses produksi menggunakan mesin yang terdiri dari mesin penggiling serta alat pres sebagai alat bantu untuk menunjang proses produksi. Selama ini, UD Sari Murni memiliki kendala untuk menghitung harga pokok produksinya dengan cara yang sangat sederhana hanya memperkirakan seberapa besar biaya yang telah dikeluarkan atau disebut dengan sistem tradisional dan belum menerapkan perhitungan yang sesuai dengan kaidah akuntansi biaya. Serta dalam perhitungan biayanya tidak menghitung secara keseluruhan biaya yang digunakan dalam proses produksi. 
Menentukan harga pokok produksi merupakan salah satu hal yang penting dalam perusahaan untuk menghitung semua biaya yang dikeluarkan untuk menghasilkan produk yang menjadi dasar dalam penentuan harga dan sebagai dasar penentuan laba bersih. Sehingga dibutuhkan metode yang tepat dalam perhitungan harga pokok produksi pada perusahaan. dalam penentuan harga pokok produksi berdasarkan metode akuntansi biaya yaitu metode full costing. Metode ini menghitung biaya produksi secara keseluruhan yang terdiri dari biaya bahan baku, biaya tenaga kerja langsung, dan biaya overhead pabrik baik yang bersifat tetap maupun variabel. Sehingga Perusahaan ini dapat menentukan harga pokok produksinya yang lebih akurat. Perusahaan ini dipilih sebagai objek penelitian karena berdasarkan jumlah produksi yang dihasilkan lebih banyak dengan waktu usaha yang lama, membuat peneliti tertarik untuk meneliti di perusahaan tersebut agar perusahaan tersebut mampu memperbaiki penentuan harga pokok produksi.

\section{METODE}

Jenis penelitian yang digunakan dalam penelitian ini adalah kualitatif dengan pendekatan deskriptif yang bertujuan untuk mengungkapkan kejadian atau fakta dalam penelitian berlangsung dengan menyuguhkan dan mendeskripsikan apa yang sebenarnya terjadi. Lokasi dalam penelitian ini adalah UD Sari Murni Kelurahan Brang Biji Kecamatan Sumbawa. Sumber data yang digunakan dalam penelitian ini yaitu data primer dan data sekunder. Tahapan yang dilakukan peneliti dalam menganalisis data adalah :1) pengumpulan data yang diperoleh dari hasil wawancara,observasi dan dokumentasi;2) mereduksi data dengan memfokuskan pada data-data yang berkaitan dengan biaya-biaya penentuan harga pokok produksi; 3) Uji Keabsahan data dengan triangulasi sumber,teknik dan waktu; 4) penyajian data, melakukan uraian singkat dari data yang diperoleh di sajikan berupa data atau infromasi yang belum di olah; 5) Analisis data, Menjabarkan biaya per unit yang di hasilkan dalam penggunaan perusahaan selama satu periode atau tahun 2017 dan melakukan perbandingan antara perhitungan harga pokok produksi perusahaan dengan metode full costing sehingga dapat mengetahui selisih dari kedua metode; 6) Menarik kesimpulan

\section{PEMBAHASAN}

\section{Deskripsi perhitungan biaya produksi}

1. Bahan Baku

Bahan baku merupakan bahan utama yang diolah dalam proses produksi hingga menjadi produk jadi. Pembelian bahan baku dalam proses produksi sebagai berikut :

- Kedelai Lokal ( Tahu) satu ton dalam satu kali pembelian

- Kedelai Impor (Tempe) satu ton dalam satu kali pembelian 
- Garam (Fermentasi Tahu) dalam setahun pembelian sebanyak 4.300 liter atau 215 jrigen.

- Ragi (Fermentasi Tempe) pembelian sebanyak 288 bungkus dalam setahun.

\section{Tabel 4.2}

Biaya Bahan Baku Langsung Produk Tahu dan Tempe

\begin{tabular}{|c|c|c|c|c|c|}
\hline jenis kedelai & $\begin{array}{l}\text { Hari } \\
\text { kerja }\end{array}$ & $\begin{array}{l}\text { Penggunaan } \\
\text { per hari }\end{array}$ & Volume & $\begin{array}{c}\text { Harga } \\
\text { (Rp) }\end{array}$ & $\begin{array}{c}\text { Jumlah biaya } \\
\text { (Rp) }\end{array}$ \\
\hline $\begin{array}{l}\text { Kedelai Lokal } \\
\text { ( Tahu) }\end{array}$ & $\begin{array}{l}357 \\
\text { hari }\end{array}$ & $120 \mathrm{~kg}$ & $42.840 \mathrm{Kg}$ & $7.000 / \mathrm{Kg}$ & Rp.299.880.000 \\
\hline $\begin{array}{c}\text { Kedelai } \\
\text { Impor(Tempe) }\end{array}$ & $\begin{array}{c}96 \\
\text { hari }\end{array}$ & $100 \mathrm{~kg}$ & $\mathrm{Kg}^{9.600}$ & $8.200 / \mathrm{kg}$ & Rp. 78.720 .000 \\
\hline Garam & $\begin{array}{l}357 \\
\text { hari }\end{array}$ & 12 liter & 4.284 liter & $1.250 /$ liter & Rp. $\quad 5.355 .000$ \\
\hline Ragi & $\begin{array}{c}96 \\
\text { hari }\end{array}$ & 3 bungkus & $\begin{array}{c}288 \\
\text { bungkus }\end{array}$ & 12.500 & Rp. $\quad 3.600 .000$ \\
\hline
\end{tabular}

Jumlah

Rp.387.555.000

Sumber: UD. Sari Murni

Berdasarkan tabel 4.2, jumlah pembelian bahan baku untuk produk tahu dan tempe memiliki perbandingan antara 42.840 perkilogram dan 9.600 perkilogram yang dapat diproduksi sehingga total selama tahun 2017 adalah sebesar $52.440 \mathrm{~kg}$ atau 52.44 ton. Untuk hasil tersebut didapatkan dari jumlah hari kerja selama setahun 357 dikalikan dengan penggunaan per hari yaitu 120 kilogram sehingga mendapatkan volume pemakaian sebanyak 42.480 kilogram yang dikalikan dengan harga perkilogram masing-masing kedelai yaitu Rp.7000 lokal dan Rp.8.200 impor dan memperoleh jumlah biaya yang dikeluarkan selama setahun untuk masing-masing kedelai yaitu Rp.299.880.000 dan Rp.78.720.000 total keseluruhan menjadi Rp.378.600.000. Sedangkan untuk penggunaan garam, dalam sehari membutuhkan 12 liter garam yang dikalikan dengan jumlah hari kerja sehingga menghasilkan 4.284 liter atau 214,2 jrigen dengan harga perliternya yaitu Rp.1.250 sehingga pembelian dalam setahun yaitu Rp.5.355.000 karena dalam 1 jrigen memiliki volume 20 liter sehingga perusahaan tidak dapat membeli sesuai dengan kebutuhan yang tepat namun harus disesuaikan dengan jumlah volume dalam 1 jrigen sehingga perusahaan membeli 215 jrigen yang menghasilkan 4.300 liter. Untuk penggunaan ragi dalam sehari membutuhkan 3 bungkus untuk satu kali produksi, hari kerja untuk setahun yaitu 96 hari sehingga menghasilkan penggunaan dalam setahun yaitu 288 bungkus. Hasil tersebut didapatkan dari penggunaan sehari 3 bungkus yang dikalikan dengan jumlah hari kerja dalam setahun yaitu 96 hari sehingga menghasilkan 288 bungkus dalam setahun dengan harga perbungkusnya yaitu Rp12.500 sehingga total 
pengeluaran yaitu Rp3.600.000. Total keseluruhan pengeluaran perusahaan dalam setahun yaitu Rp378.555.000.

2. Biaya Tenaga Kerja Langsung

Tenaga kerja merupakan Karyawan yang mengubah bahan baku mentah menjadi produk. Seluruh tenaga kerja yang ada di industri ini merupakan tenaga kerja langsung yakni sebanyak 4 orang tenaga kerja yang melakukan seluruh proses produksi.

\section{Tabel 4.3}

Biaya Tenaga Kerja Langsung Variabel (Tahu)

\begin{tabular}{|c|c|c|c|c|c|}
\hline Jenis & $\begin{array}{c}\text { Jumlah } \\
\text { hari } \\
\text { kerja }\end{array}$ & $\begin{array}{c}\text { Pemakaian } \\
\text { cetak } \\
\text { perhari }\end{array}$ & Volume & Biaya & Jumlah \\
\hline
\end{tabular}

Tahu

357 hari

\begin{tabular}{|c|c|}
\hline 60 & 21.420 \\
\hline
\end{tabular}

$\mathrm{Rp}$

53.550 .000

Jumlah

Rp

53.550.000

Sumber: UD.Sari Murni

Tabel 4.4

Biaya Tenaga Kerja Langsung Tetap (Tempe)

\begin{tabular}{cccccc} 
Jenis & Pegawai & Perbulan & Tahun & Gaji/tahun & Jumlah \\
\hline Pengolahan & 2 & 1.550 .000 & 12 bulan & 37.200 .000 & Rp37.200.000 \\
Pengemasan & 2 & 600.000 & $\begin{array}{c}12 \\
\text { bulan }\end{array}$ & 14.400 .000 & Rp14.400.000 \\
& & & & & Rp51.600.000
\end{tabular}

Sumber: UD. Sari Murni

Upah setiap karyawan diberikan berdasarkan hasil yang diperoleh pencetak tahu, dengan gaji percetaknya sebesar Rp.2.500, sehingga diperoleh gaji pertahun dari pegawai tersebut sebesar Rp.53.550.000. keseluruhan biaya yang dikeluarkan oleh perusahaan didapatkan dari jumlah pemakaian sebanyak 120 kilogram yang menghasilkan 60 cetak sehari dikalikan dengan jumlah hari kerja sehingga menghasilkan 21.420 cetak dalam setahun sehingga upah yang harus dibayarkan selama setahun yaitu sebesar Rp. 53.550.000. Sedangkan Pada produk Tempe diproduksi melalui dua tahap, dalam tahap pertama yaitu pengolahan yang dilakukan oleh 2 pegawai tetap sedangkan tahap kedua pengemasan yang dilakukan oleh 2 pegawai sementara. Gaji yang diberikan untuk proses produksi pengolahan dan pengemasan yaitu 
perbulan. Dalam sebulan pegawai bagian pengolahan memperoleh gaji sebesar Rp1.550.000 sedangkan untuk pegawai pengemasan memperoleh gaji sebesar Rp 600.000. Dalam pengolahan tempe ada 2 orang maka dikalikan dengan jumlah gaji dalam sebulan yang diterima yaitu Rp1.550.000 dan dikalikan dalam setahun sehingga menghasilkan Rp37.200.000, sedangkan bagian pengemasan terdapat 2 orang yang dikalikan dengan jumlah gaji dalam sebulan yang diterima yaitu Rp14.400.000 menghasilkan total keselurahan biaya tenaga kerja yang dikeluarkan oleh perusahaan adalah sebesar Rp51.600.000/tahun.

3. Biaya Overhead Pabrik

\section{Tabel 4.5}

Pemakaian Biaya Listrik Perhari

\begin{tabular}{ccccccc}
\hline Jenis & Watt & $\begin{array}{c}\text { Pemakaian } \\
\text { per jam }\end{array}$ & $\begin{array}{c}\text { Jumlah } \\
\text { Watt }\end{array}$ & $\begin{array}{c}\text { Jumlah } \\
\text { Kwh }\end{array}$ & Tarif & Jumlah \\
\hline $\begin{array}{l}\text { Mesin } \\
\begin{array}{l}\text { Press } \\
\text { Kecil }\end{array}\end{array}$ & 250 & 2,5 & 625 & 0,625 & $1.467,28$ & 917,05 \\
Mesin Air & 300 & 4 & $\begin{array}{l}1200 \\
\text { Jumlah }\end{array}$ & 0,12 & $1.467,28$ & 1761 \\
\hline
\end{tabular}

Tabel 4.6

Biaya Listrik Tahun 2017

\begin{tabular}{|c|c|c|c|}
\hline Jenis & Hari pemakaian & $\begin{array}{c}\text { Pemakaian } \\
\text { perhari }\end{array}$ & Total \\
\hline $\begin{array}{c}\text { Mesin } \\
\text { Press Kecil }\end{array}$ & 96 hari & 917,05 & 88.037 \\
\hline \multirow[t]{2}{*}{ Mesin Air } & 357 hari & 1761 & 628.677 \\
\hline & \multicolumn{2}{|c|}{ Jumlah } & 716.714 \\
\hline
\end{tabular}

Untuk pemakaian listrik dalam sehari menghasilkan 917,05 untuk penggunaan mesin press kecil sedangkan untuk mesin air sebesar 1761 . Hasil tersebut didapatkan dari jumlah pemakaian lamanya mesin digunakan (jam) yang dikalikan dengan jumlah watt setiap mesin yang menghasilkan jumlah watt keseluruhan pemakaian yang kemudian dibagikan dengan per Kwh listrik yaitu 1000. Dalam penentuan tarif melihat kapasitas kilometer yang digunakan oleh pemilik yaitu 1.300 ampermeter dengan tarif 1.467,28. Dari hasil tersebut dikalikan dengan pemakaian Kwh yang digunakan sehingga menghasilkan dalam sehari jumlah tersebut. Berdasarkan tabel diatas menyatakan bahwa penggunaan biaya listrik pada perusahaan dalam satahun yaitu 716.714. Hasil tersebut didapatkan dari lama pemakaian dalam sehari 
yang dikalikan dengan jumlah hari pemakaian dalam setahun untuk proses produksi produk tahu dan tempe

Tabel 4.7

Biaya Bahan Baku Tidak Langsung Tahun 2017

\begin{tabular}{llrlll}
\hline No & Jenis & Volume & $\begin{array}{l}\text { Harga } \\
\text { per item }\end{array}$ & \multicolumn{2}{c}{ Total Harga } \\
\hline 2. & Plastik Kuning & $39 \mathrm{bal}$ & 20.000 & $\mathrm{Rp}$ & 780.000 \\
3. & Plastik Putih & $35 \mathrm{bal}$ & 15.000 & $\mathrm{Rp}$ & 525.000
\end{tabular}

Jumlah

Rp.1.305.000

Plastik kuning sebanyak 39 bal sedangkan palstik putih sebanyak 34 ball, dalam satu kali pembelian plastik kuning yaitu 1 ball dalam pemakaian 1 cetak tempe ukuran besar membutuhkan $50 \mathrm{~cm}$ sedangkan ukuran yang kecil membutuhkan ukuran panjang plastik 30 $\mathrm{cm}$.

Tabel 4.8

Biaya Peralatan

\begin{tabular}{|c|c|c|c|c|}
\hline No & Jenis & Volume & $\begin{array}{l}\text { Harga per } \\
\text { item }\end{array}$ & Total Harga \\
\hline 1. & Keranjang & 7 & 80.000 & 560.000 \\
\hline 2. & Jambangan & 4 & 1.800 .000 & 7.200 .000 \\
\hline 3. & Rembangan & 1 & 3.000 .000 & 3.000 .000 \\
\hline 4. & Cetakan Tahu & 3 & 80.000 & 240.000 \\
\hline 5. & Wajan & 4 & 1.000 .000 & 4.000 .000 \\
\hline 6. & Ember kecil & 15 & 20.000 & 300.000 \\
\hline 7. & $\begin{array}{l}\text { Papan } \\
\text { Pendingin }\end{array}$ & 80 & 25.000 & 2.000 .000 \\
\hline 8. & Mesin Tahu & 1 & 5.000 .000 & 5.000 .000 \\
\hline 9. & Bak besar & 7 & 65.000 & 455.000 \\
\hline 10. & $\begin{array}{l}\text { Rak Peletakan } \\
\text { Tempe }\end{array}$ & 8 & 250.000 & 2.000 .000 \\
\hline 11. & Mesin Tempe & 1 & 2.000 .000 & 2.000 .000 \\
\hline 13. & $\begin{array}{l}\text { Alat } \\
\text { press/sealer }\end{array}$ & 2 & 250.000 & 500.000 \\
\hline 14. & Alat pres & 2 & 1.000 .000 & 2.000 .000 \\
\hline 15. & $\begin{array}{l}\text { Cetakan } \\
\text { Tempe }\end{array}$ & 180 & 8000 & 1.440 .000 \\
\hline $\begin{array}{l}16 . \\
\text { Jum }\end{array}$ & $\begin{array}{l}\text { Dandang } \\
\text { lah }\end{array}$ & 1 & 1.500 .000 & $\begin{array}{r}1.500 .000 \\
\mathbf{3 4 . 1 9 5 . 0 0 0}\end{array}$ \\
\hline
\end{tabular}


Tabel 4.9

Biaya perlengkapan (Habis Pakai)

\begin{tabular}{ccccccr}
\hline No & Jenis & $\begin{array}{c}\text { Pemakaian } \\
\text { /hari }\end{array}$ & $\begin{array}{c}\text { Hari } \\
\text { kerja }\end{array}$ & Volume & $\begin{array}{c}\text { Harga per } \\
\text { item }\end{array}$ & Total Harga \\
\hline 1. & Solar & 2 liter & 357 & 714 liter & 10.000 & 7.140 .000 \\
2. & Sekam & 20 karung & 357 & $\begin{array}{c}7.140 \\
\text { karung } \\
8\end{array}$ & 7.000 & 49.980 .000 \\
3. & Kain & & & 20.000 & 160.000
\end{tabular}

$\mathbf{5 7 . 2 8 0 . 0 0 0}$

Sumber :UD. Sari Murni

Data diatas menunjukkan bahwa pemakaian untuk solar dalam sehari yaitu 2 liter kemudian dikalikan dengan hari kerja yang dapat volume dalam setahun yaitu 714 liter yang dikalikan dengan harga per item sehingga menghasilkan total harga yaitu 7.140.000 kemudian untuk pemakaian sekam dalam sehari membutuhkan 20 karung dan dikalikan dengan hari kerja yang mendapatkan volume dalam setahun sebanyak 7.140 mendapatkan total pengeluaran yaituRp.49.980.000 sehingga keseluruhan total pemakaian dalam setahun yaitu Rp57.280.000 yang ditambah dengan kain yang mudah rusak sehingga termasuk dalam biaya yang habis pakai dan tidak bertahan lama dengan pengeluaran sebesar Rp.160.000.

Tabel 4.10

Biaya Penyusutan

\begin{tabular}{llcccc}
\hline No & \multicolumn{1}{c}{ Jenis } & $\begin{array}{c}\text { Harga } \\
\text { Perolehan } \\
\text { (Rp) }\end{array}$ & $\begin{array}{c}\text { Umur } \\
\text { Ekonomis } \\
\text { (Tahun) }\end{array}$ & $\begin{array}{c}\text { Nilai } \\
\text { Residu }\end{array}$ & $\begin{array}{c}\text { Biaya } \\
\text { Penyusutan }\end{array}$ \\
\hline 1. & Gedung & 70.000 .000 & 20 & 3.500 .000 & 3.325 .000 \\
2. & $\begin{array}{l}\text { Mesin } \\
\quad \begin{array}{l}\text { Penggilingan } \\
\text { Tempe }\end{array}\end{array}$ & 2.000 .000 & 8 & 250.000 & 218.750 \\
3. $\quad \begin{array}{l}\text { Mesin } \\
\quad \begin{array}{l}\text { Penggiling } \\
\text { Tahu }\end{array}\end{array}$ & 5.000 .000 & 8 & 625.000 & 546.875 \\
4. $\quad \begin{array}{l}\text { Jambangan } \\
\text { 5. }\end{array}$ & $\begin{array}{l}\text { Papan } \\
\quad \text { Pendingin }\end{array}$ & 2.000 .000 & 4 & 500.000 & 375.000 \\
6. & Alat Press & 2.000 .000 & 4 & 500.000 & 375.000 \\
7. & Wajan & 4.000 .000 & 4 & 1.000 .000 & 750.000
\end{tabular}




\begin{tabular}{|c|c|c|c|c|c|}
\hline 8. & Rembangan & 3.000 .000 & 4 & 750.000 & 562.500 \\
\hline 9. & $\begin{array}{l}\text { Rak } \\
\text { Peletakan } \\
\text { Tempe }\end{array}$ & 2.000 .000 & 4 & 500.000 & 375.000 \\
\hline 10. & Dandang & 1.500 .000 & 4 & 375.000 & 281.250 \\
\hline 11. & Keranjang & 560.00 & 4 & 140.000 & 105.000 \\
\hline 12 & Cetakan tahu & 240.000 & 4 & 60.000 & 45.000 \\
\hline 13 & $\begin{array}{l}\text { Cetakan } \\
\text { tempe }\end{array}$ & 1.440 .000 & 4 & 360.000 & 270.000 \\
\hline 14 & Ember Kecil & 300.000 & 4 & 75.000 & 56.250 \\
\hline 15 & Bak Besar & 455.000 & 4 & 113.750 & 85.313 \\
\hline 16 & Sealer & 500.000 & 4 & 125.000 & 93.750 \\
\hline \multicolumn{5}{|c|}{ Jumlah } & .8 .166 .87 \\
\hline
\end{tabular}

Berdasarkan tabel 4.10 untuk mengetahui umur ekonomis dari setiap peralatan dilihat dari tahun perolehan yaitu sebagai berikut :

- Gedung, pada tahun 2000 perusahaan melakukan renovasi secara kseluruhan untuk mengubah bangunannya menjadi gedung permanen

- Mesin penggiling tahu, mesin penggiling tempe dan jambangan pada tahun 2012 perusahaan membeli mesin baru dan melakukan renovasi pada tempat jambangan untuk mengatasi keroposan tempat dan pendeknya penungkuan.

- Papan pendingin, Alat press, wajan, rembangan, rak peletakan tempe, dandang, keranjang, Ember kecil, Bak besar, Sealer, Cetakan Tempe dan Cetakan Tempe, pada tahun 2016.

Tabel 4.12

Biaya Overhead Pabrik Variabel

\begin{tabular}{lr}
\hline Overhead Pabrik Variabel & Jumlah \\
\hline Biaya Bahan Baku Penolong & 1.305 .000 \\
Biaya Listrik & 716.714 \\
Biaya Perawatan Mesin & 500.000 \\
Biaya perlengkapan & 57.280 .000 \\
Jumlah & Rp.59.801.714 \\
\hline
\end{tabular}


Tabel 4.13

Biaya Overhead Pabrik Tetap

Overhead Pabrik Tetap Jumlah
Biaya peralatan
34.195 .000
Biaya Penyusutan
8.166 .875

Jumlah

42.361.875

Tabel 4.14

Persediaan Akhir Desember 2017

\begin{tabular}{cccc}
\hline Jenis & Volume & Harga & Total Biaya \\
\hline Kedelai impor & $261 \mathrm{~kg}$ & 8.200 & 2.140 .200 \\
Air garam & 16 liter & 1.250 & 20.000 \\
plastik kuning & 0,6 ball & 20.000 & 12.000 \\
Plastik putih & 0,5 ball & 15.000 & 7.500 \\
& Jumlah & & $\mathbf{2 . 1 7 9 . 7 0 0}$ \\
\hline
\end{tabular}

Persediaan perusahaan pada tahun 2017 tersisa terdiri dari bahan baku langsung yaitu kedelai impor tersisa sebanyak 261 kilogram dari pembelian yaitu 9.600 kilogram yang dibeli hanya 9.339 kilogram yang digunakan sehingga totalnya mencapai 2.140.200. sedangkan bahan baku tidak langsung yaitu air garam plastik kuning dan plastik putih. Air garam yang merupakan proses fermentasi untuk tahu yang tersisa sebanyak 16 liter Penggunaan sehari untuk pengemasan tempe ukuran besar membutuhkan ukuran $50 \mathrm{~cm}$ dengan jumlah cetakan yang didapatkan sebanyak 80 cetak sehingga dalam sehari dibutuhkan 4.000 $\mathrm{cm}$ atau 40 meter dalam 1 ball memiliki panjang 100 meter sehingga pengunaannya menjadi 0,4 ball yang dikalikan dengan jumlah hari kerja selama setahun menghasilkan 38,4 ball /tahun sedangkan pembelian dalam setahun sebanyak 39 ball sehingga menyisahkan 0.6 ball. Sementara untuk ukuran yang kecil memiliki ukuran $30 \mathrm{~cm}$ dengan jumlah cetakan dalam sehari 120 cetak sehingga membutuhkan 3.600 $\mathrm{cm}$ ukuran plastik putih atau 36 meter dalam 1 ball memiliki panjang 100 meter sehingga pengunaannya menjadi 0,36 ball yang dikalikan dengan jumlah hari kerja selama setahun menghasilkan 34,5 ball /tahun sedangkan pembelian dalam setahun sebanyak 35 ball sehingga menyisahkan 0.5 ball.

Biaya Bahan baku Per Unit 
Tabel 4.15

Biaya Bahan Baku Pemakaian kedelai tahu

\begin{tabular}{llcccc}
\hline Produk & $\begin{array}{c}\text { Unit } \\
\text { Produksi }\end{array}$ & $\begin{array}{c}\text { Pemakaian } \\
\text { untuk } \\
\text { cetak (kg) }\end{array}$ & $\begin{array}{c}\text { Jumlah } \\
\text { pemakaian }\end{array}$ & $\begin{array}{c}\text { Harga } \\
\text { per kg }\end{array}$ & Total \\
Tahu & 21.420 & & & \\
& cetak & $\begin{array}{c}2 \mathrm{~kg} \\
\text { Jumlah }\end{array}$ & $42.840 \mathrm{~kg}$ & 7.000 & 299.880 .000 \\
\multicolumn{2}{l}{ Sumber: UD.Sari Murni }
\end{tabular}

Tabel 4.16

Perbandingan Proporsi Pemakaian Bahan Baku Kedelai Tempe

\begin{tabular}{ccccc}
\hline Bahan Baku & luas cetakan & $\begin{array}{c}\text { pemakaian untuk } \\
\text { cetak }\end{array}$ & $\begin{array}{c}\text { Jumlah } \\
\text { proporsi }\end{array}$ & Proporsi \\
\hline Besar & $450(35 \times 15)$ & 80 cetak & 36.000 & 1,25 \\
Kecil & $240(20 \times 12)$ & 120 cetak & 28.800 & 1 \\
\hline
\end{tabular}

Tabel 4.17

Biaya Bahan Baku Pemakaian Kedelai Tempe

\begin{tabular}{ccccc}
\hline Produk & Proporsi & $\begin{array}{c}\text { Jumlah } \\
\text { Pemakaian }\end{array}$ & Harga per kg & Total \\
\hline $\begin{array}{c}\text { Tempe } \\
\text { besar }\end{array}$ & 1,25 & 55,56 & 8.200 & 569.490 \\
$\begin{array}{c}\text { Tempe } \\
\text { kecil }\end{array}$ & 1 & 44,44 & 8.200 & 364.408
\end{tabular}

100

933.893

Jumlah

9.339

Pemakaian kedelai dalam setahun yaitu $42.840 \mathrm{~kg}$, dengan jumlah unit produksi yang dihasilkan sebanyak 21.420 cetak. Penggunaan dalam sehari perusahaan menggunakan $120 \mathrm{~kg}$ yang menghasilkan 60 cetak. Dalam 1 cetak membutuhkan $2 \mathrm{~kg}$ kedelai, harga per kg kedelai yaitu Rp.7000. sehingga dalam pertahun perusahaan mengeluarkan biaya sebesar Rp.299.880.000.

Untuk ukuran tempe besar memiliki luas cetakan $450(35 \times 15)$ yang dikalikan dengan hasil dalam produksi yaitu 80 cetak sehingga mendapatkan jumlah proporsinya yang menjadi dasar penentuan proporsi yaitu didapatkan dari jumlah proporsi 36.000 dibagi dengan 28.800 dan mendapatkan proporsi 1,25 sedangkan untuk ukuran tempe kecil memiliki luas cetakan yaitu 240 (20x12) dikalikan dengan hasil cetakan dalam produksi 120 cetak menghasilkan 28.800 dengan jumlah proporsi 1 . Sedangkan untuk biaya bahan baku pemakaian dari tempe ukuran besar proporsi yang 1,25 dikalikan dengan jumlah pemakian 55,56 yang didaptkan dari total proporsi yang 1,25 ditambahkan dengan 1 sehingga menghasilkan 2,25 sedangkan perusahaan memproduksi 100 
kg maka keseluruhan proporsi 2,25 dibagikan dengan 100 menghasilkan 44,44 sehingga total seluruh yang 100 dikurangi dengan 44,44 menghasilkan 55,56. Perolehan total dari masing jumlah pemakaian dikalikan dengan harga/kg 8.200 menghasilkan 567.490. dan 364.408 total 933.893 dibagi dengan jumlah pemakaian keseluruhan 100 maka menjadi 9.339 yang digunakan dalam setahun oleh perusahaan.

Tabel 4.19

Biaya Bahan Baku Tidak Langsung Per Hari

\begin{tabular}{lcccc}
\hline No & Jenis & Penggunaan & Harga & Total Harga \\
\hline 1. & Plastik Kuning & 0.4 ball & 20.000 & 8.000 \\
2. & Plastik Putih & 0,36 bal & 15.000 & 5.400 \\
Jumlah & & & $\mathbf{6 5 . 9 0 0}$ \\
Sumber : UD Sari Murni
\end{tabular}

Tabel 4.20

Bahan Baku tidak langsung Per tahun 2017

\begin{tabular}{ccccc}
\hline \multicolumn{2}{c}{ Jenis } & Penggunaan & Harga & Total Harga \\
\hline $\begin{array}{c}\text { Tempe } \\
\text { ukuran besar }\end{array}$ & $\begin{array}{c}\text { Plastik } \\
\text { kuning }\end{array}$ & 38,4 bal & 20.000 & 768.000 \\
$\begin{array}{c}\text { Tempe } \\
\text { ukuran kecil }\end{array}$ & $\begin{array}{c}\text { Plastik } \\
\text { putih }\end{array}$ & 34,5 bal & 15.000 & \\
& & & & 517.500
\end{tabular}

Jumlah

Rp.1.285.500

Sumber: UD.Sari Murni

\section{Harga Pokok Produksi}

Tabel 4.23

Perhitungan Harga Pokok Produksi Metode Perusahaan dan Metode Full Costing

$\begin{array}{cccc}\text { Keterangan } & \text { Metode } & \text { Metode Full } & \text { Perbanding } \\ & \text { Perusahaan } & \text { Costing } & \text { Selisih }\end{array}$

Pembelian

$388.860 .000 \quad 388.860 .000$

0

Bahan baku tidak

langsung

$(1.305 .000)$

$(1.305 .000)$

0

387.555 .000

387.555 .000

0

Persediaan akhir Desember 2017

$(2.179 .700)$

0

Bahan baku yang 
digunakan

$$
\begin{array}{lll}
385.375 .300 & 385.375 .300 & 0
\end{array}
$$

Tenaga kerja langsung $\quad 87.300 .000 \quad 105.150 .000 \quad 17.850 .000$

overhead pabrik

Bahan baku tidak langsung $\quad 1.305 .000 \quad 1.305 .000 \quad 0$

$\begin{array}{llll}\text { Biaya listrik } & 716.714 & 716.714 & 0\end{array}$

$\begin{array}{llll}\text { Biaya Perlengkapan } & 57.280 .000 & 57.280 .000 & 0\end{array}$

Biaya Penyusutan $\quad 8.166 .875$

Biaya peralatan

34.195 .000

Biaya Perawatan Mesin $\quad 500.000 \quad 500.000$

$\begin{array}{llll}\text { Total biaya produksi } & 59.801 .714 & 102.163 .589 & 42.361 .875\end{array}$

\begin{tabular}{llll} 
Harga Pokok Produksi & 532.477 .014 & $\mathbf{5 9 2 . 6 8 8 . 8 8 9}$ & $\mathbf{6 0 . 2 1 1 . 8 7 5}$ \\
\hline
\end{tabular}

selisih nilai harga pokok produksi yaitu sebesar Rp.60.211.875 selisih tersebut terjadi karena disebabkan perbedaan nilai pada biaya overhead pabrik saat melakukan perhitungan harga pokok produksi. Nilai biaya overhead pabrik yang dihasilkan apabila menggunakan metode perusahaan adalah sebesar Rp.59.801.714, sedangkan dengan metode full costing nilai biaya overhead lebih besar yaitu sebesar Rp.102.163.589 sehingga selisih dari total biaya produksinya sebesar Rp.42.361.875 Perbandingan selisih tenaga kerja langsung sebesar Rp.17.850.000, dikarenakan biaya yang seharusnya dihitung dalam perusahaan karena pemilik melakukan proses produksi. 


\section{Kesimpulan}

\section{PENUTUP}

1. Perhitungan harga pokok produksi yang dilakukan oleh perusahaan UD Sari Murni masih menggunakan metode sederhana, dimana biaya-biaya yang diakui dalam perhitungan harga pokok produksi adalah biaya bahan baku, biaya tenaga kerja langsung dan biaya overhead pabrik variabel. Total keseluruhan biaya produksi yang dihasilkan dari perhitungan biayabiaya tersebut adalah Rp.59.801.714 Sedangkan harga pokok produksi yaitu sebesar Rp.532.477.014

2. Perhitungan harga pokok produksi menggunakan metode full costing mengakui seluruh biaya produksi yaitu biaya bahan baku, biaya tenaga kerja langsung dan biaya overhead pabrik baik yang bersifat tetap maupun variabel sehingga informasi mengenai harga pokok produksi lebih akurat dan sesuai dengan kaidah akuntansi. Total biaya produksi yang dihasilkan menggunakan metode full costing adalah sebesar Rp.102.163.589 Sedangkan harga pokok produksinya yaitu Rp.592.688.889

3. Perbandingan hasil perhitungan harga pokok produksi menggunakan metode perusahaan dan metode full costing, nilai harga pokok produksi yang dihasilkan memiliki perbedaan. Perhitungan yang dihasilkan menggunakan metode perusahaan lebih rendah daripada metode full costing. Selisih nilai harga pokok produksi kedua metode yaitu sebesar Rp.60.211.875.

\section{Saran}

Berdasarkan simpulan diatas, ada beberapa saran yang dapat diberikan dalam penelitian ini yaitu sebagai berikut :.

1. Bagi perusahaan UD Sari Murni. Metode harga pokok produksi yang seharusnya digunakan pada perusahaan yaitu full costing karena metode ini merinci seluruh biaya seperti biaya bahan baku, biaya tenaga kerja dan biaya overhead baik yang bersifat tetap maupun variabel yang dikeluarkan pada saat kegiatan produksi, sehingga informasi yang dihasilkan lebih akurat dan membantu perusahaan dalam menetapkan harga jual produk serta mampu memaksimalkan laba yang diperoleh.

2. Bagi peneliti selanjutnya, diharapkan dapat mendapatkan dokumendokumen secara lengkap baik dengan cara wawancara, observasi maupun dokumentasi minsalkan seperti mengenai pembelian bahan baku atau disebut dengan faktur pembelian. 


\section{DAFTAR PUSTAKA}

Anwar \& Anshari Lidia Fasi. (2010). "Harga Pokok Produksi Dalam Kaitannya Dengan Penentuan Harga Jual Untuk Pencapaian Target Laba Analisis". Jurnal Akuntansi dan Keuangan Vol. 1, No. 1 September 2010 halaman 79-94.

Cahyani, Galuh Fitri Nur. (2010). "Analisis Perhitungan Harga Pokok Produksi Pada Pabrik Tahu Sari Langgeng Kutoarjo Dengan Metode Full Costing". Jurnal Ekonomi dan Bisnis jurusan Akuntansi Universitas PGRI Yogjakarta.

Carter, William K. (2009) Akuntansi Biaya. Buku 1, Edisi 14. Jakarta: Salemba Empat..

Hansen dan Mowen. (2001). Akuntansi Manajemen. Jakarta : Salemba Empat

Komara \& Sudarma Ade. (2016). “Analisis Penentuan Harga Pokok Produksi Dengan Metode Full Costing Sebagai Dasar Penetapan HargaJual Pada CV Salwa Meubel”. Jurnal Ilmia Ilmu Ekonomi Vol. 5. Edisi 9.

Mulyadi. (2001). Akuntansi Manajemen : Konsep, Manfaat dan Rekayasa. Edisi Tiga, Jakarta : Salemba Empat.

Mursyidi. (2010). Akuntansi Biaya. Bandung: PT Refika Aditama.

Perindustrian,Kementrian.(2018).JurnalNasional.Websitehttp://www.kemenperin.go.i d/artikel/7221/Ukuran-Tempe-Siasati-Kenaikan-Kedelai diakses pada tanggal 23 Juli 2018

Rumampuk, Maria Sifra. (2013). "Perbandingan Perhitungan Harga Pokok Produk Menggunakan Metode Activity Based Costing Dan Metode Konvensional Pada Usaha Peternakan Ayam CV Kharis Di Kota Bitung”. Jurnal EMBA Vol. 1 No. 4 Desember 2013, Hal. 637-645.

Saputri, Yohana. (2014). "Perhitungan Harga Pokok Produksi Dengan Metode Full Costing Pada UMKM Kerupuk Cap Laksa". Jurnal Ekonomi dan Bisnis Universitas Dian Nuswantoro Semarang

Setiyaningsih, Endra. (2009). "Analisis Penerapan Metode Full Costing Dalam Perhitungan Harga Pokok Produksi Untuk Penetapan Harga Jual". Jurnal Ekonomi dan Bisnis Vol. 1 No. 1 Agustus 2009.

Slat, Andre Hendri. (2013). "Analisis Harga Pokok Produksi Dengan Metode Full Costing Dan Penentuan Harga Jual”. Jurnal EMBA Vol. 1 No. 3 Juni 2013, Hal.110-117.

Sugiyono. (2010). Metode Penulisan Kuantitatif, Kualitatif dan R \& D. Bandung: CV. Alfabeta

Undang-Undang Republik Indonesia Nomor 20 Tahun 2008 Tentang Usaha Mikro,Kecil dan Menengah

Wasilah, Wiratna. (2015). Akuntansi Biaya Teori dan Penerapannya. Yogyakarta: Pustaka Baru Press. 